13. Knapp.-Trans. Amer. Ophthal. Soc., Vol. XXV, 1927.

14. Voegele.-Klin. Monatsbl.f. Augenheilk., Vol. LXXIV, p. 775, 1925.

15. Elschnig.-Zeitschr. f. Augenheilk., Vol. XXXIX, p. 189.

16. Parkes Weber. - Proc. Roy. Soc. of Med., 1929.

17. Brushfield and Wyatt.-Brit. Jl. of Children's Diseases, 1927 and 1928.

18. Aynsley.-Brit. Jl. of Children's Diseases, 1928.

19. MacRae.-Brit. Jl. of Ophthal., February, 1929.

20. Thomson, Ernest.-Brit. Jl. of Ophthal., March, 1929.

21. Foster Moore.-Brit. Jl. of Ophthal., May, 1929.

22. Henderson, E. E.-Brit. Jl. of Ophthal., 1920.

23. Milles.-Trans. Ophthal. Soc. U.K., 1884.

24. Lawford.-Trans. Ophthal. Soc. U.K., 1885.

25. Krause.-Zeitschr. f. Augenheilk., July, 1929.

26. Junius.-Zeitschr. f. Augenheilk. July, 1929.

\title{
ANNOTATIONS
}

\section{Ophthalmic School Inspection}

The Annual Report of the Metropolitan Asylums Board for the year 1928-29 has a short section devoted to ophthalmic conditions. As is well known ophthalmic cases among the L.C.C. schools have been under the care of the Board since 1897, and for the past five years cases of interstitial keratitis have been able to be admitted to the White-Oak School at Swanley.

Cases are drawn from the Metropolitan area, but, also by agreement, from extra-Metropolitan Boards of Guardians.

" To meet certain difficulties which had arisen in connection with children under the care of the Guardians and said to have a tendency to ophthalmia, arrangements were made by the Board in 1913 for monthly inspections by a surgeon skilled in the recognition and treatment of ophthalmia, of children at the Central London District School. The objects of this periodical visitation are, first, the earlier recognition and isolation of infective cases and a reduction in the number of cases which might otherwise be attacked by the disease and have to be dealt with specially by the Board in its ophthalmia school, and, secondly, to avoid occupation of accommodation by certain cases of a mild nature which are curable in a few days at their own institutions by means of suitable applications." These arrangements have worked well and are being continued.

The reports of the visiting ophthalmic surgeon at the Central London District School, Mr. F. A. C. Tyrrell, and of the visiting ophthalmic surgeon at White-Oak, Swanley, Mr. M. S. Mayou, are included. 
At White-Oak 226 cases were admitted during the year : these are scheduled under the following headings.-Trachoma, 24. Chronic conjunctivitis, 38. Blepharitis, 48. Phlyctenular ophthalmia, 76. Follicular conjunctivitis, 1. Corneal ulcer, 13. Muco-purulent conjunctivitis, 2. Interstitial keratitis, 24. 290 cases were remaining over from the previous year. Of the total the following numbers were discharged cured.-Trachoma, 61. Chronic conjunctivitis, 38. Blepharitis, 27. Phlyctenular ophthalmia, 76. Follicular conjunctivitis, 7. Corneal ulcer, 7. Muco-purulent conjunctivitis, 1. Interstitial keratitis, 28. One case absconded.

Mr. Tyrrell's report makes it clear that the periodical inspection at the Central London District School has resulted in a considerable reduction in the number of admissions to the Board's ophthalmia schools.

These results speak for themselves. If such are obtainable in the London area by regular school inspection, it is pertinent to ask why similar methods cannot be adopted outside the Metropolis?

We understand that the Council of British Ophthalmologists has approached the Ministries of Health and Education in this matter, and we hope that a satisfactory answer will be forthcoming in the near future.

\section{The Wilmer Ophthalmological Institute}

The William Holland Wilmer Ophthalmological Institute was formally opened on October 15 and 16, 1929.

The idea of founding a central eye institute in the United States, with Dr. Wilmer as Director, is not one of mushroom growth; for, as long ago as the year 1920, Mrs. Henry Breckinridge was instrumental in appointing the provisional committee to undertake the necessary spade work, which has culminated in what must be the most complete and up-to-date ophthalmological centre in the world.

In 1922 matters had advanced so far that a deed of incorporation was framed and passed for the purpose of " establishing and endowing, and, if necessary, maintaining and conducting an institution for the care, treatment and surgery of the human eye, as well as research in the field of medical science as it relates to the eye."

The Johns Hopkins Hospital, at Baltimore, was obviously the proper venue for such an institution ; and early in January, 1925, the General Education Board of the Rockefeller Institute promised 